\title{
Narrative philosophy of religion: apologetic and pluralistic orientations
}

\author{
Mikel Burley ${ }^{1}$ (]
}

Received: 4 July 2019 / Accepted: 9 October 2019 / Published online: 16 October 2019

(c) The Author(s) 2019

\begin{abstract}
Recent decades have witnessed a growing interest in narrative both in certain areas of philosophy and in the study of religion. The philosophy of religion has not itself been at the forefront of this narrative turn, but exceptions exist-most notably Eleonore Stump's work on biblical stories and the problem of suffering. Characterizing Stump's approach as an apologetic orientation, this article contrasts it with pluralistic orientations that, rather than seeking to defend religious faith, are concerned with doing conceptual justice to the range of possible human perspectives, both religious and nonreligious. By discussing various examples, the article makes a case for narrative philosophy of religion, especially in its pluralistic form.
\end{abstract}

Keywords Apologetics · Fyodor Dostoevsky $\cdot$ Hindu mythology $\cdot$ Narrative · Pluralism $\cdot$ Problem of evil $\cdot$ Suffering $\cdot$ Elie Wiesel

From the 1980s and 1990s onwards, certain areas of philosophical inquiry have been strongly invigorated by a turn to narrative art—including novels, plays and filmsand to the concept of narrativity more generally. Discussion of narrative art, especially great works of literature, has had a particular impact upon moral philosophy, with figures such as Stanley Cavell, Richard Eldridge and Martha Nussbaum being among the pioneers in this field. ${ }^{1}$ More recently, other philosophers have engaged with literature and with film in innovative ways, reflecting upon how narrative fiction can poignantly represent certain difficulties that confront us in our lives-difficulties to which standard forms of philosophy often fail to do justice because of a greater concern with building arguments that have generalizable conclusions than

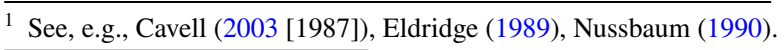

Mikel Burley

m.m.burley@leeds.ac.uk

1 School of Philosophy, Religion and History of Science, University of Leeds, Leeds LS2 9JT, UK
} 
with bringing out the messy complexities of everyday experiences. ${ }^{2}$ Also notable has been the turn to narrativity in the philosophy of personhood by those who argue "that the self needs to be understood in terms of narrative" (Rudd 2012, 1). ${ }^{3}$

In the broad field of the study of religion, narrative has featured most prominently in Christian theology, with some theologians contending that religious faith has a deeply narrative structure-that "[s]tories do not merely decorate or illustrate, but provide the substance of faith" (Tilley 1985, xvii), for it is through the telling of stories that the distinctively human story can "be bound in with that of God and Jesus" (Mauz 2009, 262). ${ }^{4}$ The philosophy of religion, by contrast, has been somewhat slow to pick up on the significance of narrative. Rare exceptions include Stewart Sutherland's insightful examination of the themes of atheism and faith in relation to Dostoevsky's The Brothers Karamazov (Sutherland 1977) and two collections of essays by D. Z. Phillips (1982, 2006). A more influential intervention has been Eleonore Stump's major study of biblical narratives as a vehicle for thinking through the problem of suffering (Stump 2010)—a study that has in turn elicited numerous responses, both critical and complimentary. ${ }^{5}$ What all these works demonstrate is the promising potential of a turn to narrative in the philosophy of religion.

The purpose of the present article is twofold. One of its aims is to establish not that the turn to narrative is necessarily superior to other ways of engaging in the philosophy of religion, but that it constitutes a coherent and productive approach, or cluster of approaches, capable of yielding richer and more nuanced understandings of religious possibilities than is often supplied by other methods. In connection with this aim, I shall, for the most part, be using the phrase "narrative philosophy of religion" to identify the type of approach in which I am interested. What I mean by this phrase is not—or, at any rate, not primarily - a type of philosophy that takes a narrative form itself rather than the kind of more recognizably argumentative form that is typical of philosophical essays and monographs. There have, of course, been important philosophers who have authored literary works that are rightly celebrated for their philosophical content: figures such as Voltaire, de Beauvoir, Camus and Sartre immediately come to mind. And elsewhere I have argued that certain literary works that were not composed by philosophers can nevertheless be regarded as participating in philosophy of religion, broadly construed (Burley 2017). In this article, however, what I mean to designate by the phrase "narrative philosophy of religion" is the type of philosophical inquiry into religion that, without becoming a work of narrative art itself, takes seriously the contribution of narrative sources to our philosophical understanding of religion and, in the course of developing a philosophical

\footnotetext{
${ }^{2}$ Work by Diamond (2003; reprinted in Cavell et al. 2008) and Mulhall (2009) is especially relevant. On film as a philosophical and ethical medium, see Mulhall (2016) and Sinnerbrink (2016).

${ }^{3}$ See especially work by MacIntyre (2007), Taylor (1989) and Ricoeur (1984-1988). For critical perspectives, see Strawson (2004) and Lamarque (2007).

${ }^{4}$ For an accessible survey of narrative theological approaches up to 1987, see Comstock (1987). For more recent perspectives, see Ganzevoort et al. (2014). For a critical view, see Murphy (2007).

${ }^{5}$ Notable responses include Draper (2011), Fales (2013), Efird and Worsley (2015). See also Stump (2012).
} 
argument, engages with such sources in a sustained manner rather than, at most, citing them only cursorily as mere decoration.

Beyond making a case for narrative philosophy of religion in general, the second aim of this article is to distinguish between two orientations in narrative philosophy of religion. For the most part, I shall refer to these two orientations as apologetic and pluralistic respectively, though in certain instances other terms might serve just as well. What I am calling an apologetic orientation to narrative philosophy of religion is one that sees its principal task as being to defend religion-and most commonly this will be Christianity in particular-from critical philosophical attacks. A primary example is Stump's aforementioned work on the problem of suffering, for Stump is not interested merely in exploring how this problem is treated in various narrative sources; rather, she wishes to draw upon biblical narratives to inform her argument "that suffering can be redeemed for the sufferer in personal relationship, that heartbreak can be woven into joy through the reciprocity of love" (2010, xix). What I am calling a pluralistic orientation, meanwhile, is one that seeks not to defend either Christianity or any other religious system, but rather to promote a deeper understanding of a plurality of perspectives, both religious and nonreligious. Sutherland and Phillips are among the exemplars of this approach. Although each of them is more knowledgeable about, and more personally interested in, Christianity than in any other religion, they both strive to bring out the intelligibility of multiple points of view without overtly endorsing any of them as the true, or most rational, position to adopt.

While not simply dismissing the apologetic orientation, I emphasize the merits of a pluralistic orientation to narrative, especially as a means of diversifying the range of religious traditions and forms of religiosity that are amenable to being discussed in the philosophy of religion. To this end, in addition to the examples of Sutherland and Phillips, I also include a section on work by the Indologist Wendy Doniger O'Flaherty on Hindu mythology as a philosophical resource. A growing chorus of voices has been calling in recent years for an expansion of philosophy of religion, both methodologically and in terms of subject matter, and it is my contention that a turn towards narrativity is one among other important means of rising to that challenge. What I am calling apologetic and pluralistic orientations, respectively, will each be discussed below. A theme running through the discussion will be conceptions of, or responses to, evil and suffering, for not only is this among the paramount themes in the relevant literature, but it also facilitates a higher degree of comparative analysis across my various examples than would otherwise be the case. First, however, let us consider the more general question of why narrativity might be of philosophical interest at all.

\section{Why narrativity?}

Much of what needs to be said in this article about why a narrative approach to philosophy of religion might be a fruitful one to pursue will come out in the discussions of the apologetic and pluralistic orientations that follow. Before coming to those discussions, however, it is worth pausing to register some important observations about 
narrativity that can be gleaned from other philosophical areas, especially moral philosophy. These observations may help to strengthen the case for taking seriously narrative philosophizing in general, thereby also motivating the case for looking more rigorously at narrative philosophy of religion in particular.

Among the salient motivations for regarding literature, or narrative art more broadly, as being in some sense internal rather than external to philosophy is a twofold conviction in the importance of style. First, there is the conviction that the style or form of a piece of writing "is not separable from philosophical content, but is, itself, a part of content" (Nussbaum 1990, 3). Second, is the related conviction that, in the case of certain perspectives on human life or the world, these perspectives can be adequately articulated only by means of narrative (ibid., 7). When combined together, these two convictions generate the view that narrative artworks can make valuable contributions to our understanding of what it is to be human, and of what it means to live a good human life, that are not translatable into the dry emotionless prose of standard academic philosophy. Whether the contributions of the narrative artworks in question may then be treated as properly philosophical will, inevitably, depend to a great extent on how capaciously the notion of philosophy is conceptualized. In the case of moral philosophy, or ethics, Nussbaum opts for "the very simple Aristotelian idea that ethics is the search for a specification of the good life for a human being" (1990, 139). She chooses this formulation not arbitrarily but because she considers it "broadly correct" and "sufficiently inclusive to command wide agreement" (1990, 139)_but also because of its potential to encompass what certain works of literary fiction are in the business of doing.

In an essay that is largely sympathetic to Nussbaum's project, Cora Diamond (1983) takes as her starting point Nussbaum's recognition of the need for an expansive conception of moral philosophy if narrative art's relevance to it is to be acknowledged. For additional conceptual resources, Diamond looks to ideas from Iris Murdoch about the place that morality has in human life. In a contribution to a symposium on "Vision and Choice in Morality," Murdoch observes that our assessments of other people are not limited to their actions or choices, but extend to "something more elusive which may be called their total vision of life" or, in another metaphor, "the texture of a man's being" (Murdoch 1956, 39). While noting that it is the metaphor of vision that tends to be uppermost in Murdoch's own philosophical work, Diamond finds the term "texture of being" more evocative of what is at issue in moral philosophy's relation to literature (Diamond 1983, 162). This is the case because when we pay close attention to what many novelists offer, we see not only that it is precisely what might be termed an account of the "texture of being" of particular human lives, but also that it is offered "out of an interest we may properly call moral" (ibid.). Extending Murdoch's point, Diamond adds that it need not be only the lives of individual people to which moral reflection is directed, but also "forms of social life" (163). In passing, we might mention that these could include forms of life that are distinctly religious.

It is beyond the scope of my own discussion to enter into the debate over which conception of moral philosophy ought to be preferred. The crucial point for our present purposes is that the question of what, if anything, literature or other narrative art has to contribute to moral philosophy is inseparable from the question of what moral 
philosophy is (or ought to be). Those who operate with a narrow conception-one which views moral philosophy's task primarily in terms of questions about the permissibility, impermissibility or obligatoriness of certain types of action-are apt to see narratives as relevant only insofar as they can furnish "evidence" in support of or against general action-guiding principles (see Raphael 1983, 1). Those who are favourable to broader conceptions, meanwhile, will tend to be more sympathetic to the view that, beyond merely supplying examples or counterexamples, narrative art can itself be-to invoke a phrase from Cavell_- "in the condition of philosophy" (Cavell 1979, 14; see also Mulhall 2016, 85, 88).

Thus, what philosophy has to gain from a turn to narrative inevitably remains contested. But the fact that the turn itself facilitates a deepening of the argument over what philosophy is, or what its possibilities are, speaks in favour of taking the turn seriously. What those who recommend an expansive conception of philosophy often appreciate most about narrative sources is their ability to draw to our attention the details of particular characters and situations-details that are routinely glossed over in the broad-brushed theoretical claims of mainstream philosophy. By refusing to simplify the complexities of the everyday, and by striving to bring those complexities to life in vivid description, narrative art can heighten our awareness of certain features of human existence-its "texture of being"- that are otherwise readily missed or ignored. This, at any rate, is among the signal benefits that many philosophers see in narrative materials: the affordance of richly contextualized scenarios that invite cognitive, imaginative and emotional involvement from the audience, as opposed to thinly formulated arguments that are forced to traffic in simplifications by virtue of the high level of generality that they attempt to achieve. With these points in view, we are now in a position to examine different ways in which narrative sources have been engaged with in the philosophy of religion.

\section{An apologetic orientation to narrative philosophy of religion}

Narrative philosophy of religion with an apologetic orientation has much in common with narrative theology. Both enterprises appeal to religious stories, principally in the form of biblical scripture, to support the viability of faith in the face of "the challenges of Enlightenment thinkers to the cognitive plausibility of Christian doctrine" (Oakes 1992, 38), and central among these is the challenge to the belief in a God of love that results from the pervasiveness of evil and suffering in the world. Eleonore Stump situates her major work, Wandering in Darkness: Narrative and the Problem of Suffering (2010), within the field of philosophy of religion, though it is no less an attempt at Christian apologetics than are the numerous products of narrative theologians.

Early on in her project, Stump ventures an incisive critique of much of what passes for philosophy of religion in the analytic tradition. While recognizing its virtues of argumentative rigour and logical precision, Stump cautiously concurs with those who complain of the "aridity" and "narrowness" typified by this style of philosophizing $(2010,23)$. A particular weakness that Stump highlights, citing Bernard Williams as a critical ally in this regard, is the apparent inability of many 
analytic philosophers to do justice in their discussions to the intricacies of interpersonal encounters and relationships. Instead of invoking "complex cases drawn from real life or from the world's great literature," Stump charges, such philosophers typically make do with under-described thought-experiments featuring perfunctorily sketched characters (with generic names such as "Smith," "Jones," etc.) (2010, 25). To overcome these deficiencies, Stump proposes a marriage between standard methods of analytic philosophy on the one hand and "the study of narrative" on the other (ibid.). Articulating this marriage in terms of a union between two modes of knowledge, she designates these modes "Dominican" and "Franciscan" respectively (after the Catholic religious orders of those names).

In Stump's vocabulary, Dominican knowledge is what is commonly referred to in philosophical parlance as propositional knowledge or "knowledge that" (i.e. knowledge that such-and-such is the case); it is a type of knowledge that is acquirable via the methods of analytic philosophy. Franciscan knowledge, meanwhile, is gained by acquaintance, and among its varieties is knowledge of persons. Characterizing this latter knowledge as "direct, intuitive, non-propositional," Stump adds that, though normally enabled by direct acquaintance with a person, it "can also be transmitted to a greater or lesser extent by stories" (Stump 2012, 199). Stump's central claim concerning biblical narratives is, then, that these provide the attentive reader with Franciscan knowledge both of the characters in the story and of the lifeworld they inhabit, much as visiting a foreign country facilitates knowledge of its people and places $(2012,198)$. For Stump's purposes, the crucial consequence of this is that the insight gained into the world of the narrative enables one to understand how the suffering of certain characters is redeemed: it is redeemed on account of its engendering a deepened relationship with God on the part of the characters in question. Moreover, it is in "the details of the narrative of a life" that we learn how suffering can, at least in some circumstances, be received "as a gift" (2010, xviii).

Stump's exposition and analysis of four biblical stories is too extensive and elaborate to be discussed in detail here. In order to explicate the contrast that I wish to make between apologetic and pluralistic narrative philosophizing, I shall focus on her treatment of one biblical narrative, the story of Job; in doing so, I borrow a line of criticism from Wes Morriston.

In her discussion of the Book of Job, Stump is careful to acknowledge that "interpretations of texts can invite one to see the text in a certain light, but they cannot compel assent as philosophical arguments are meant to try to do" $(2010,178)$. Nevertheless, the light in which Stump invites us to see the story of Job is liable to strike many readers as excessively one-sided in its sanguinity. Focusing especially on the passages in which God is portrayed as speaking directly to Job, Stump maintains that these speeches "suggest that God's relationship to all his creatures is personal, intimate, and parental" (191). Even in the difficult case of a passage about female ostriches, which are described as incompetent mothers who forget that leaving their eggs on the ground could result in the eggs' being trampled by wild animals, Stump discerns a "loving" and "tender" insinuation. There is tenderness here, Stump opines, because it is God who reminds the ostrich and safeguards the eggs that she "so forgetfully left vulnerable" (189). If we read the biblical passage as a whole, 
however, we see that the ostrich is described as dealing "cruelly with her young, as if they were not hers," and as lacking fear because God has deprived her of wisdom and understanding (Job 39:16-18). ${ }^{6}$ It is hard to see how Stump's insistence on God's parental tenderness could be made to fit with such descriptions.

Similarly, when God asks Job rhetorically who it is that "provides for the raven its prey, when its young ones cry to God, and wander about for lack of food" (Job $38: 41$ ), Stump zeros in on the phrase "cry to God" as exemplifying how intimate the relationship is between God and the animals he has created (Stump 2010, 189). As Morriston points out, however, the feeding of young ravens-in cases when they are fed at all-is part of a broader context in which prey animals are killed by predators, since the ravens scavenge from the carcasses that the predators leave behind (Morriston 2017, 233). The natural world, as depicted in the Book of Job, is a place of violence and death at least as much as it is one of nurturing love and benevolence, and yet Stump downplays the violence and accentuates what she perceives as the caring relationship in which God stands to his creatures. Morriston thus regards Stump as reading the text through the filter of her own assumptions concerning God's providential plan and its portrayal in the Bible rather than as making a genuine effort to do justice to the narrative itself $(2017,229)$.

Morriston's critique of Stump's idealized and romanticized interpretation of God's speeches, and of other aspects of the story of Job, is well taken. By exaggerating the extent to which God is depicted as a loving parent in the story, Stump presents a one-sided construal that, in the absence of a counterbalancing reading such as Morriston's, risks obscuring the variety of interpretations to which the text is amenable. While there is nothing inherently wrong with propounding a partisan interpretation of a narrative source, it is essential that readers of the interpretation remain alert to the interpreter's agenda, which in Stump's case is decidedly apologetic and theodicean.

Before moving on to consider a pluralistic narrative orientation, it will be instructive to note a deep tension in the book of Stump's that we have been examining. The tension concerns Stump's attitude towards discussing the Holocaust or Shoah in the philosophy of religion. As important background for pinpointing the tension, two elements of Stump's book may be mentioned. First is the fact that she chooses as the book's incipit an anonymous poem, found on a wall at the notorious Auschwitz concentration camp, that declares grace and wonder to be "hard to see, / hard to embrace, for / those compelled to / wander in darkness" (quoted in Stump 2010, xx). ${ }^{7}$ It is from the poem's final line that her book's title, Wandering in Darkness, is derived. Second is Stump's assertion that the Holocaust is among the evils that "are not fit subjects for the academic exploration of the problem of evil," for to treat it "as one more example or counter-example in academic disputation" would be "unspeakably awful" (2010, 16). The tension that interests me is not, strictly, between Stump's use of the poem from Auschwitz and her refusal to discuss the Holocaust directly, since it is one thing to pay homage to victims of the Holocaust in

\footnotetext{
${ }^{6}$ Revised Standard Version (Holy Bible 1952, 471).

7 Stump derives this English rendering of the poem from Czarnecki $(1989,11)$.
} 
an epigraph and another to dwell upon the terrible details of their suffering as part of one's argument. The tension, rather, is between, on the one hand, Stump's apparent recognition that there is something baffling about the horror of the Holocaust-a horror that renders attempts to incorporate it into philosophical discourse inadequate at best and downright offensive at worst - and, on the other hand, the claim of her book as a whole to have supplied a response, by means of interpretations of biblical narratives, to every form of suffering there is.

While acknowledging that instances of suffering more horrendous than those recounted in the biblical stories she has discussed occurred during both the Holocaust and the era of American slavery, Stump maintains that, considered together, the four stories with which she deals-namely, those of Job, Samson, Abraham, and Mary of Bethany-afford a comprehensive typology among which "[a]ll modes of suffering" may be found, "even if many of its species are missing" $(2010,375)$. Given that she regards her overall argument as amounting to a "defense"-in the technical philosophical sense of an account that shows, not the truth of, but the coherence of the claim that God has reasons for allowing suffering that are "morally sufficient" to "defeat" the negative value of the suffering itself (see Stump 2010, 13) - the contention Stump is making on behalf of her project becomes puzzling. The contention seems to be that, without having discussed the Holocaust or American slavery directly, a defence has nevertheless been provided of how the "modes" of suffering endured by victims of those, and other, dreadful historical events could be consistent with the propitious designs of a God of love. If this is not a fair summary of the claim Stump is making, then it becomes unclear how the argument of her book amounts to a defence at all, for if paradigms of extreme suffering such as those experienced by victims of slavery or the Holocaust are to be left aside (on the grounds that discussing them in this context would be "unspeakably awful"), then in what sense has a defence that "defeats the badness of suffering" $(2010,13)$ been supplied?

The difficulty of understanding the intended scope of Stump's argument derives from a clash between her totalizing apologetic ambition and her recognition that certain "species" of suffering are simply not appropriate subjects of philosophical "explanation" or "defense." What I have also contended in this section is that an apologetic orientation to narrative philosophy of religion encourages a one-sided interpretive approach. This in itself need not be problematic, provided it is balanced by readers' having access to alternative interpretations of the relevant narrative sources. What a pluralistic orientation actively fosters, however, is precisely such a two-sided, or multisided, approach, thereby encouraging a richer appreciation of interpretive possibilities. Insofar, then, as one values an appreciation of this sort, one has a reason for approving of a pluralistic orientation, which I shall now elaborate in relation first to Sutherland, second to Phillips, and third to O'Flaherty. 


\section{Pluralistic narrative philosophy of religion 1: Stewart Sutherland on Dostoevsky}

The publication of Sutherland's that is most pertinent in this context is his Atheism and the Rejection of God: Contemporary Philosophy and "The Brothers Karamazov" (1977), in which he analyses how Dostoevsky's final novel vividly depicts, first, a compelling form of atheism in the character of Ivan Karamazov, and second, the deeply religious form of life both of Ivan's younger brother Alyosha and of Alyosha's mentor, the elder monk Father Zossima. Like Stump, Sutherland is keen to show that a story can advance a perceptive account of the place that suffering has in human lives and of how individuals respond to the existence of suffering in the world - an account that cannot readily be paraphrased in the more austere prose of standard philosophical exposition. Unlike Stump, however, Sutherland is not trying to advocate for one particular attitude to suffering, an attitude that views the negative value of suffering as being outweighed by the closeness of the relationship with God that it can expedite. Rather, Sutherland's purpose is to demonstrate that divergent responses to the existence of suffering can each be viable, and that Dostoevsky himself ensures that his novel does justice to the competing responses, laying them before the reader without didactically commending one and denigrating the other. If readers are to learn anything from the novel, it is that a plurality of responses to the world, a plurality of ways of being human, can make sense and exhibit a high degree of moral seriousness without its being the case that we can decide between them on the basis of a knockdown philosophical argument.

Through the character of Ivan Karamazov, Dostoevsky voices the strongest conceivable moral objection to the claim that the world is overseen and cared for by a God of love. That objection consists in the incontrovertible observation that we inhabit a world in which the most terrible atrocities occur, including the torture and agonizing deaths of children. By describing such incidents, Ivan - and hence Dostoevsky - refuses to allow the defender of religion to hide from the grisly reality by taking refuge in the conjectures of theoretical discourse. In this respect, the tools of narrative are deployed to the end of starkly confronting Christian faith with its greatest challenge, and in the person of Ivan we are shown someone who, out of a professed "love for humanity," feels compelled to reject any "entrance ticket" into a world where obscenities such as the torture of children are forgiven (Dostoyevsky 1900 [1880], 291). (In passing, we might note that Stump, in contrast to Dostoevsky's Ivan, restricts her deliberations to the suffering "of adult human beings who are mentally fully functional" (2010,4), thereby again casting doubt upon her claim to have covered all the "modes" of suffering there are.)

Having articulated the case against faith in a God of love and mercy, Dostoevsky proceeds, in Book 6 of the novel, to develop an "answer to all those atheistical propositions" in the form not of a "point by point" riposte, but of "an artistic picture" (Dostoevsky, in Coulson 1962, 224). As Sutherland puts it, Dostoevsky imagines (and thus enables his readers to imagine) a form of life in which the distinctively Christian vocabulary-comprising concepts such as those of God, worship, eternal life, miracles, prayer and so on—can be seen to retain a profound meaning and 
vivacity for Christian believers, notwithstanding the extent to which it has been harangued by Ivan in terms that many readers are apt to find morally persuasive (see Sutherland 1977, 86-87). This resurrection, as it were, of Christian discourse is performed through Dostoevsky's portrayal of the sincere religious lives of Father Zossima and his disciple Alyosha.

As Sutherland sees it, and as I have concurred elsewhere (Burley 2017, 116), the issue of whether Dostoevsky's novel is successful in presenting a possibility of religious sense - a possible way of living out a Christian life-does not require that it convince anyone of the truth of Christian doctrine. Sutherland follows Mikhail Bakhtin in regarding The Brothers Karamazov as a "polyphonic" novel, in which a "plurality of independent ... voices" are brought together without being fused into one (Bakhtin 1984, 6). The plurality remains undiluted, for "No single vision could encompass all that Dostoevsky refused to omit" (Sutherland 1977, 140).

Clearly, much more could be said both about the work of Dostoevsky himself and about the ways in which Sutherland explicates that work in order to make a case for its philosophical value. For my purposes here, however, enough has been said to indicate how the novel, and what Sutherland makes of it, may be treated as instances of pluralistic narrative philosophy of religion. The orientation is pluralistic inasmuch as it seeks to elucidate more than one perspective, or more than one "texture of being" (to borrow the phrase that Diamond adapts from Murdoch), as opposed to building a one-sided defence of a religious ideology. To illustrate the orientation further, I turn now to work by D. Z. Phillips.

\section{Pluralistic narrative philosophy of religion 2: D. Z. Phillips on Elie Wiesel}

A characteristic of Phillips's philosophical work in general is its emphasis on "possibilities of sense" or "possibilities of meaning"-the clarification of possible forms of human life rather than the attempt to establish the superiority of any one of them. This emphasis carries over into his work in the philosophy of religion, where he strives to "discuss possibilities of religious sense, often ignored by contemporary advocates and critics of religion" (2006, xi). When selecting narrative sources as his focus, Phillips prioritizes those that, by grappling with the gritty realities of people's impulses, emotions and commitments, tend to avoid "the distortions of human suffering so often found in religious apologetics" (ibid.). Especially poignant in this connection is Phillips's treatment of Elie Wiesel's harrowing autobiographical accounts of his experiences as a teenage Jewish prisoner in the Auschwitz and Buchenwald concentration camps towards the end of the Second World War.

We might note immediately that Phillips shared Eleonore Stump's revulsion at the thought of treating the Holocaust, or any other occurrence of extreme human suffering, "as one more example or counter-example in academic disputation on the problem of evil" (Stump 2010, 16, quoted earlier). Phillips frequently rails against the type of instrumentalist thinking of theodicists who suppose that finding a religious "explanation" of the Holocaust is simply a matter of establishing what Richard 
Swinburne (among others) describes as "the greater good which allowing ... such horrible things to occur makes possible" (Swinburne 1998, 107), such as the opportunities for displaying bravery, sympathy and other virtues (ibid., 151). Both Phillips and Stump would agree that even entering into such cost-benefit analyses is, as Phillips puts it, already to have travelled too far along a road "we shouldn't have turned into in the first place" $(2004,71)$. But Phillips discovered more subtle ways of reflecting philosophically on the implications for religious faith of immense human tragedies, including the Holocaust, and Wiesel's memoirs are among the sources that facilitated those reflections.

Like Ivan Karamazov in Dostoevsky's novel, Wiesel refuses to romanticize the horrors of extreme suffering; he is not afraid to point out the extent to which torture and humiliation can crush a person's spirit and provoke debased behaviour. He recounts, for instance, how, on a long forced March from one concentration camp to another, the son of an elderly rabbi hurried ahead of his father, hoping thereby "to free himself of a burden that could diminish his own chance for survival" (Wiesel $2006,91)$, and how, when packed into cattle wagons, the inmates would fight among themselves over scraps of bread thrown to them by passers-by, sometimes killing even members of their own family in the process (101). These are experiences that, for Wiesel and for many of his fellow prisoners, far from engendering a closer relationship with God, destroyed their faith. This is a fact that Phillips recognizes: that encounters with evil can, and often do, obliterate a person's ability to believe and trust in God, and it is through the testimony of witnesses such as Wiesel that we are enabled all too vividly to understand that response. Yet Phillips also wishes to acknowledge that this is not always the case. For some victims of catastrophic horrors, faith is retained or even strengthened. To make the point, Phillips cites a prayer found next to the body of a dead child at the Ravensbrück camp: "And may the love that we have known be their forgiveness" (quoted in Phillips 2004, 269). ${ }^{8}$ The purpose of citing such a prayer is not to furnish evidence in support of an argument that this is how religious believers ought to respond to brutal oppression; it is to indicate that this response is possible. A believer in God might regard such faith as a gift of grace. For the pluralistic philosopher of religion, it may indeed be something to marvel at — as a human possibility_but it remains one possibility among others.

In the examples I have so far adumbrated, from Sutherland on Dostoevsky and from Phillips on Wiesel, we see ways in which narrative sources, whether novelistic or autobiographical, may assist philosophical reflection upon aspects of faith, and upon the loss or rejection thereof, in broadly Christian or Jewish contexts. It is also important to the case I am making in favour of a pluralistic orientation to narrative philosophy of religion that at least one example be given of how this orientation can help to widen the range of topics discussed in philosophy of religion beyond the usual domain of "theism" construed in Christian-centric or, at most, in loosely Abrahamic terms. Phillips's own work on non-Abrahamic religions tends to draw more upon cultural anthropological sources than on narrative ones (see esp. Phillips

\footnotetext{
${ }^{8}$ In a more common translation of the prayer, this line reads "and when they come to judgement let all the fruits which we have borne be their forgiveness" (see, e.g., Appleton 1985, 112, prayer 367).
} 
2001), so in the next section I instead look to work by the Indologist Wendy Doniger

O'Flaherty on the concept of evil in relation to Hindu mythological stories.

\section{Pluralistic narrative philosophy of religion 3: evil and suffering in Hindu mythology}

Philosophy of religion as it is practised in Western academic settings has struggled to find ways of overcoming the constraints of a relatively fixed canon of topics that revolve around the rationality of a "classical theistic" conception of God. The socalled problem of evil as it is standardly formulated is one of those topics, presupposing, as it does, that God is to be conceived of as, among other things, omnipotent, omniscient and omnibenevolent. One of the implications of a turn to narrative is that the focus is shifted-away from forms of argumentation that involve marshalling premises in support of a conclusion that can be stated as a concise proposition, and towards more nuanced accounts of the lived experience of determinate characters, whose responses to suffering may help to open our minds and imaginations to human possibilities we had previously neglected or undervalued. More than this, however, the turn to narrative can also provide a route into the examination of modes of religiosity beyond the usual repertoire of Western philosophical preoccupations. Exemplary of this potential is much of Wendy Doniger O'Flaherty's work, including her book The Origins of Evil in Hindu Mythology (1976). ${ }^{9}$

By using, as a resource for reflecting upon the concept of evil, the variegated body of narrative texts deriving from multiple Hindu (and also some Buddhist and Jain) traditions, O'Flaherty demonstrates how philosophical ideas may be found outside of what are normally treated as properly philosophical works. Her remark that "scholars have overlooked the problem of evil in Indian thought because they have sought it in philosophy rather than in mythology" $(1976,7)$ might thus also be regarded as a plea to revise the assumption that a sharp distinction obtains between the philosophical and the mythological, whether in Indian or in other cultural traditions.

Once the turn to mythology is made, there comes into view a wealth of material-indeed, a veritable "embarras de richesse" $(1976,10)$-relevant to the concept of evil and to closely related themes. One of the most important findings of O'Flaherty's research is, precisely, that evil and suffering have been thought about in numerous ways over the long course of Indian religious, philosophical and cultural history. Unsurprisingly, one of the most salient of these ways is to invoke the doctrine of karma and rebirth, according to which there is, built into the structure of the universe, a retributive function that generates, either in this life or in some future reincarnation, unpleasant experiences or circumstances for those who breach the code of right action and pleasant experiences or advantageous circumstances for

\footnotetext{
9 From 1989 onwards, Wendy Doniger O'Flaherty has published under the name Wendy Doniger. Besides the book that I discuss here, publications of philosophical interest include O'Flaherty (1980, 1984) and Doniger (1998, 1999).
} 
those who fulfil their duties. What sustained attention to the mythological literature reveals, however, is that this doctrine of retributive karma has often been supplemented by or even subordinated to other conceptions of the roots of evil, such as the notion of malevolent demons who repeatedly try to supplant the benign gods as rulers of the universe or the further notion of an ultimately supreme deity who incorporates evil into the divine plan for reasons known only to the deity himself or herself-or for no specific reason at all. To give even a brief summary of all the mythic themes that O'Flaherty examines is beyond the scope of my present discussion. As an illustrative example, however, I shall here outline an aspect of how gender-related and sexual ethical values can be expressed through mythic narratives concerning the origin of evil and sin.

In this connection, O'Flaherty reminds us how Indian myths are typically set within a comprehensive cosmological framework, involving cyclical cosmic ages that last for thousands of years each. As one age gives way to the next, there is a continuous degeneration of morality and a corresponding decline in lifespan and general well-being. Eventually, a cosmic collapse or conflagration or inundation occurs, followed by a period of quiescence and then a renewal of the golden age, at which point the serial degeneration begins again. Articulations of sexual ethics are embedded in these cosmological narratives by the association of different methods of reproduction with the successive cosmic ages: originally, "people were born by imagination," but then different forms of sexual intercourse became necessary (O'Flaherty 1976, 27). In one version of this type of myth, enunciated in the Mārkandeya Purāna (c. third to ninth centuries CE) and the Kürma Purāna (c. eighth century CE), it is said that procreation originally happened without the need for women to menstruate; at that time, people lived long, fulfilling and virtuous lives "without desire" and "without any affliction"; then, as an insidious physical and moral corruption spread, "lustful passion arose, and because of their passion women began to menstruate, and they conceived again and again"; greediness escalated, trees died because they had been "fenced in," hunger increased and cities had to be built to house the excessively growing populace (O'Flaherty 1976, 27).

As O'Flaherty brings out in her analysis, stories such as the one just summarized give voice to the view, derived from ascetic strands of ancient Brahmanical orthodoxy, that the production of offspring is to be kept separate from sexual passion. Menstruation, often symbolic both of female sexuality and of spiritual impurity, is linked through the narrative not only to overpopulation, but also to an ensuing scarcity of food and a move from rural to urban habitation, replete with its stresses and strains (ibid., 28). Building upon O'Flaherty's exposition and interpretation, we might add that mythic narratives of this sort contribute not so much to the presentation of philosophical arguments for a certain origin of sin or suffering, as to the construction of an elaborate worldview, of which distinctive values and attitudes are in large part constitutive. In this case, the values and attitudes are concerned especially with women's sexuality and with erotic impulses more broadly; in other myths, meanwhile, different features of human existence and its place in the world are apt to be foregrounded. The value of studying such myths in the context of philosophy of religion is not to form, or reinforce, one-sided pictures of Hindu conceptions of womanhood, since a diverse range of representations of women and goddesses is 
available in Hindu mythology as a whole. Rather, it is, again, to discover a point of entry into religiously inflected ways of thinking and responding to the world that are not only of intrinsic philosophical interest, but also transcend the standard Western philosophical fixation on narrow conceptions of theism.

\section{Concluding remarks}

The preceding three sections have been intended not as an exhaustive exposition of what a pluralistic orientation to narrative philosophy of religion has to offer, but as a selection of poignant examples that illustrate the orientation's potential. Narrative approaches constitute one among several directions that may productively be pursued by those who wish to diversify the subject matter and methods of philosophy of religion. What I have sought to expose in my discussion is that an apologetic orientation is liable to result in one-sided treatments of the narrative sources. Provided readers have access to alternative interpretations of the sources at issue, this need not be disastrous. But there remains the likelihood that the apologetic proponents' own readings will be driven by preformed ideological agendas rather than by a sustained willingness to do justice to subtleties and possible ambivalences within the texts.

A pluralistic orientation is, by its nature, internally variegated. That is why I have used the term "orientation" - to indicate that it is something broader than a strict method directed towards a single goal. Its pluralizing tendency facilitates a deepened appreciation, on the part of the reader, of plurality among the religious beliefs, practices or forms of life themselves, though there is no neatly summarizable formula for how that deepened appreciation is achieved. When prosecuted effectively, however, a pluralistic narrative orientation will amount to far more than a mere retelling or repetition of the stories that are examined. Rather, the stories are invoked and explicated by the philosopher for particular purposes, the principal purpose being to disrupt or call into question any presuppositions held by the reader, or by other philosophers, that prematurely close down the range of possible religious (or nonreligious) responses to the world. That is the critical dimension of a pluralistic narrative approach.

Owing to the pluralistic nature of a pluralistic orientation, I opted in this article to outline some indicative examples instead of constructing an abstract account. Despite the multifariousness of the examples, the fact that each of them is concerned in some way with issues of evil or suffering affords a higher degree of coherence to my comparative analysis than it would otherwise have had. In Sutherland's engagement with Dostoevsky, we see how a great work of imaginative literature can be discussed in ways that accentuate the work's philosophical richness - a richness that consists not in portraying a single ideological position, but in giving vivid expression to divergent perspectives on life and the world. By that means, both the novel itself and the philosophical discussion of it are able to participate in a pluralistic analysis of the various textures of human life, elucidating possibilities of sense rather than presuming to know the one correct perspective for everyone to adopt. Meanwhile, the example of Phillips's appeal to 
the chilling memoirs of Elie Wiesel illustrates a means by which the horrors of the Holocaust can be brought within the sphere of philosophical reflection upon horrendous evil and suffering, without the need to turn those horrors into mere evidence for an overgeneralizing thesis. As Eleonore Stump, and Phillips himself, recognize, to treat immense human tragedies in that way would be a debasement of philosophy. But what Stump has not obviously noticed is that shying away from any discussion of those tragedies while nonetheless claiming to have supplied a "defense" of every "mode" of suffering, has its own unpalatable, and implausible, implications.

Finally, I offered an example of how a narrative orientation opens the door to religiously relevant sources from diverse cultural traditions. In Wendy Doniger O'Flaherty's work on Hindu mythology we see a pluralistic sensibility in operation, since she treats the mythological sources not as merely alternative inflections of an underlying monolithic worldview, but as representing "several recognizably different conceptual attitudes to evil" (O'Flaherty 1976, 11), each of which has a place in Hinduism's "rich chord of unresolved harmony" (13).

The pluralistic strategies that I have been commending here have nothing, or very little, to do with what has commonly been called "religious pluralism" in the philosophy of religion. When a philosopher such as John Hick, for example, urges his readers to accept his "pluralistic hypothesis," he is seeking to promote the idea that all religions — or, at any rate, all the "great" ones—-subscribe to the same set of ethical values and are, in essence, directed towards the same metaphysical reality. ${ }^{10} \mathrm{~A}$ pluralistic orientation to narrative, by contrast, places the emphasis on heterogeneity and divergence. Without simply ignoring commonalities where they exist, such an orientation is one that turns to narratives as resources for attending to the details of particular cases rather than always craving to subsume those particularities under a general theory. It is in this spirit of a more radical pluralism that a pluralistic orientation to narrative can make a valuable contribution to an expanded and diversified conception of philosophy of religion. ${ }^{11}$

Open Access This article is distributed under the terms of the Creative Commons Attribution 4.0 International License (http://creativecommons.org/licenses/by/4.0/), which permits unrestricted use, distribution, and reproduction in any medium, provided you give appropriate credit to the original author(s) and the source, provide a link to the Creative Commons license, and indicate if changes were made.

\section{References}

Appleton, G. (Ed.). (1985). The Oxford book of prayer. Oxford: Oxford University Press.

Bakhtin, M. (1984 [1963]). Problems of Dostoevsky's poetics. C. Emerson (Ed. \& Trans.). Minneapolis, MN: University of Minnesota Press.

Burley, M. (2017). "The happy side of Babel": Radical plurality, narrative fiction and the philosophy of religion. Method and Theory in the Study of Religion, 29(2), 101-132.

\footnotetext{
${ }^{10}$ See esp. Hick (2004). For my own critical appraisal of Hick's purported pluralism, see Burley (2018).

${ }^{11}$ I am grateful to two anonymous referees, whose comments on a previous draft helped me to clarify my argument.
} 
Burley, M. (2018 [First Online]). Religious pluralisms: From homogenization to radicality. Sophia. https ://doi.org/10.1007/s11841-017-0636-3.

Cavell, S. (1979). The world viewed: Reflections on the ontology of film (enlarged ed.). Cambridge, MA: Harvard University Press.

Cavell, S. (2003 [1987]). Disowning knowledge in seven plays of Shakespeare (updated ed.). Cambridge: Cambridge University Press.

Cavell, S., Diamond, C., McDowell, J., Hacking, I., \& Wolfe, C. (2008). Philosophy and animal life. New York: Columbia University Press.

Comstock, G. L. (1987). Two types of narrative theology. Journal of the American Academy of Religion, 55(4), 687-717.

Coulson, J. (1962). Dostoevsky: A self-portrait. London: Oxford University Press.

Czarnecki, J. P. (1989). Last traces: The lost art of Auschwitz. New York: Atheneum.

Diamond, C. (1983). Having a rough story about what moral philosophy is. New Literary History, 15(1), $155-169$.

Diamond, C. (2003). The difficulty of reality and the difficulty of philosophy. Partial Answers: Journal of Literature and the History of Ideas, 1(2), 1-26.

Doniger, W. (1998). The implied spider: Politics and theology in myth. New York: Columbia University Press.

Doniger, W. (1999). Splitting the difference: Gender and myth in ancient Greece and India. Chicago, IL: University of Chicago Press.

Dostoyevsky, F. (1900 [1880]). The Brothers Karamazov. C. Garnett (Trans.). New York: Modern Library.

Draper, P. (2011). Review of Eleonore Stump, Wandering in darkness: Narrative and the problem of suffering. Notre Dame Philosophical Reviews, 27 July. Retrieved April 14, 2019, from https://ndpr. nd.edu/news/wandering-in-darkness-narrative-and-the-problem-of-suffering/.

Efird, D., \& Worsley, D. (2015). Critical review of Eleonore Stump's Wandering in darkness: Narrative and the problem of suffering. Philosophical Quarterly, 65, 547-558.

Eldridge, R. (1989). On moral personhood: Philosophy, literature, criticism, and self-understanding. Chicago, IL: University of Chicago Press.

Fales, E. (2013). Theodicy in a vale of tears. In J. P. McBrayer \& D. Howard-Snyder (Eds.), The Blackwell companion to the problem of evil (pp. 349-362). Malden, MA: Wiley-Blackwell.

Ganzevoort, R. R., de Haardt, M., \& Scherer-Rath, M. (Eds.). (2014). Religious stories we live by: Narrative approaches in theology and religious studies. Leiden: Brill.

Hick, J. (2004). An interpretation of religion: Human responses to the transcendent (2nd ed.). Basingstoke: Palgrave Macmillan.

Holy Bible, The: Revised standard version (1952). Division of Christian Education of the National Council of the Churches of Christ in the United States of America.

Lamarque, P. (2007). On the distance between literary narratives and real-life narratives. Royal Institute of Philosophy Supplement, 60, 117-132.

MacIntyre, A. (2007). After virtue: A study in moral theory (3rd ed.). Notre Dame, IN: University of Notre Dame Press.

Mauz, A. (2009). Theology and narration: Reflections on the "narrative theology"-debate and beyond. In S. Heinen \& R. Sommer (Eds.), Narratology in the age of cross-disciplinary narrative research (pp. 261-285). Berlin: De Gruyter.

Morriston, W. (2017). Protest and enlightenment in the Book of Job. In P. Draper \& J. L. Schellenberg (Eds.), Renewing philosophy of religion: Exploratory essays (pp. 223-242). Oxford: Oxford University Press.

Mulhall, S. (2009). The wounded animal: J. M. Coetzee and the difficulty of reality in literature and philosophy. Princeton, NJ: Princeton University Press.

Mulhall, S. (2016). On film (3rd ed.). Abingdon: Routledge.

Murdoch, I. (1956). Symposium: Vision and choice in morality. Proceedings of the Aristotelian Society, Supplementary Volumes, 30, 32-58.

Murphy, F. A. (2007). God is not a story: Realism revisited. Oxford: Oxford University Press.

Nussbaum, M. C. (1990). Love's knowledge: Essays on philosophy and literature. Oxford: Oxford University Press.

O'Flaherty, W. D. (1976). The origins of evil in Hindu mythology. Berkeley, CA: University of California Press. 
O'Flaherty, W. D. (1980). Women, androgynes, and other mythical beasts. Chicago, IL: University of Chicago Press.

O'Flaherty, W. D. (1984). Dreams, illusion, and other realities. Chicago, IL: University of Chicago Press.

Oakes, E. T. (1992). Apologetics and the pathos of narrative theology. Journal of Religion, 72(1), 37-58.

Phillips, D. Z. (1982). Through a darkening glass: Philosophy, literature, and cultural change. Oxford: Blackwell.

Phillips, D. Z. (2001). Religion and the hermeneutics of contemplation. Cambridge: Cambridge University Press.

Phillips, D. Z. (2004). The problem of evil and the problem of God. London: SCM Press.

Phillips, D. Z. (2006). From fantasy to faith: Morality, religion and twentieth-century literature (2nd ed.). London: SCM Press.

Raphael, D. D. (1983). Can literature be moral philosophy? New Literary History, 15(1), 1-12.

Ricoeur, P. (1984-1988). Time and narrative (3 vols). K. Blamey \& D. Pellauer (Trans.). Chicago, IL: University of Chicago Press.

Rudd, A. (2012). Self, value, and narrative: A Kierkegaardian approach. Oxford: Oxford University Press.

Sinnerbrink, R. (2016). Cinematic ethics: Exploring ethical experience through film. Abingdon: Routledge.

Strawson, G. (2004). Against narrativity. Ratio (New Series), 17(4), 428-452.

Stump, E. (2010). Wandering in darkness: Narrative and the problem of suffering. Oxford: Clarendon Press.

Stump, E. (2012). Wandering in darkness: Further reflections. European Journal for Philosophy of Religion, 4(3), 197-219.

Sutherland, S. R. (1977). Atheism and the rejection of God: Contemporary philosophy and 'The Brothers Karamazov'. Oxford: Blackwell.

Swinburne, R. (1998). Providence and the problem of evil. Oxford: Clarendon Press.

Taylor, C. (1989). Sources of the self: The making of the modern identity. Cambridge: Cambridge University Press.

Tilley, T. W. (1985). Story theology. Wilmington: Glazier.

Wiesel, E. (2006 [1958]). Night. M. Wiesel (Trans.). London: Penguin.

Publisher's Note Springer Nature remains neutral with regard to jurisdictional claims in published maps and institutional affiliations. 